\title{
Value Creation and Value Capture: Lessons Learnt from Indonesian Suppliers Inserted into GVC
}

\author{
Yohanes Berenika Kadarusman ${ }^{\mathrm{a}, *}$ \\ ${ }^{a}$ Universitas Prasetiya Mulya
}

\begin{abstract}
The development of global value chain (GVC) has confirmed a paradigm shift in international studies. GVC suggests that the globalization of economic activity brings about gains for developing countries through capability improvement of their firms supplying for lead firm. Nevertheless, there is only a small number of developing countries insert into GVC and successfully enhance their economy. This paper aims to understand how developing countries decide to participate in and to upgrade along GVC by taking cases from Indonesian suppliers across industries. The narratives reveal that the distribution of value creation between Indonesian suppliers and lead firm within GVC is critical for the decision making to engage and to upgrade. It indicates that the suppliers scrutinize the relationship to ensure that the value creation is not only technically feasible to fit in their existing resources and capabilities, but more importantly economically justifiable to capture more of value being created. The problem of power asymmetry tends to result in inequitable distribution of cost and benefit in value capture by Indonesian suppliers and lead firm. This makes the value creation and value upgrading within GVC less economically attractive course of action. The implication for further research on GVC should highlight the value capture particularly within governance in which power asymmetry exists, while public policy should facilitate to strengthen distinctive resources and capabilities of suppliers.
\end{abstract}

Keywords: governance; global value chain; value capture; power asymmetry; developing countries; Indonesia

JEL Classification: F55; F62; L63; L67; O53

\footnotetext{
${ }^{*}$ Corresponding Address: School of Business and Economics, Universitas Prasetiya Mulya, Jl. RA. Kartini (TB Simatupang), Cilandak Barat, Jakarta 12430, Indonesia. E-mail: yohanes.kadarusman@ pmbs.ac.id.
} 


\section{Introduction}

Globalization makes value chain simultaneously fragmented and integrated within a complex relationship comprising numerous and various firms come from all over the world, including firms from developing countries. This offers ways for the inter-firm relationship value creation and value enhancement between firms from developed and developing countries through a mutual commitment. It is expected that economic gains from globalization are larger for firms from developing countries through an improvement in firm capabilities, higher labor productivity and higher returns as reflected on the transition of developing countries toward emerging countries and ultimately developed countries. Indonesia is also not isolated from the dynamics of the globalization affecting on its firms and industries. Nevertheless, Indonesia's participation in globalization is still lagging behind other developing countries as indicated by the GVC participation index ${ }^{1}$.

In 2011, Indonesia's total GVC participation index is 43.5 that is lower than average of developing countries (48.6). The annual growth of Indonesian total GVC participation index in 1995-2011 is also lower (11.6 percent) than the average of developing countries (13.1 percent). The index indicates that the engagement of Indonesia in GVC is still limited. Furthermore, Indonesia's forward participation index is 31.5 that is much higher than the average of developing counties at 23.1. This indicates that other countries' exports (e.g. China) are supplied by Indonesia's domestic value added. The domestic value added of Indonesia in third countries exports mostly comes from mining (49.5 percent) such as coal. Therefore, Indonesia sends raw materials (instead of final goods) used as inputs or intermediates in third countries' exports. Meanwhile the backward participation index is 12.0 which is much lower than the average of developing countries at 25.5. It indicates that imports of Indonesia mostly are ultimately consumed by domestic market (as final goods) instead of used in exports (as inputs or intermediates). In sum Indonesia tends to export relatively low value added of raw materials but to import relatively high value added of final goods. In other word, GVC lead firms target Indonesia only as source of raw materials and end market that provide low value added activities. The lead firm control the two end of high value added activities, R\&D and design to support raw materials and marketing to support final market (see Figure 1). This implies that Indonesia has little opportunity to capture higher returns through its participation in GVC. The participation in GVC also provides a limited upgrading outcomes for Indonesia without moving forward and backward toward the two end of the curve.

This is reflected on Indonesia's export share in world total within the period

\footnotetext{
${ }^{1}$ The GVC participation index is defined as the ratio of a foreign inputs/value added (i.e. imports) used in a country's own exports (an upstream links or backward participation) and also the domestic value added supplied to other countries' exports (a downstream links or forward participation) (OECD, 2017).
} 


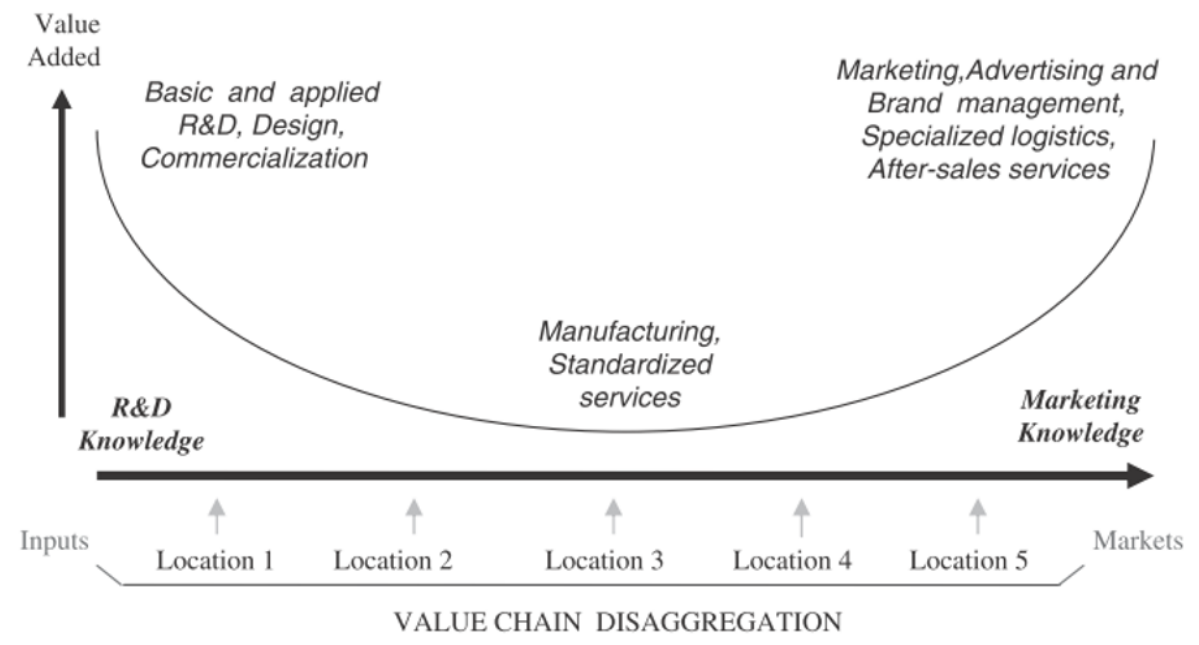

Figure 1: Value Added Activities in GVC

Source: adapted from Figure 1 (Mudambi, 2008:707)

of 1995-2011 which is stagnant at around 1.1 percent (WTO, 2017). The stagnant market share of Indonesia indicates its failures to decrease the costs of production (i.e. process upgrading) or to increase value of products (i.e. product upgrading) thus they adversely affect Indonesia's global competitiveness and its progression toward emerging countries.

In the context of Indonesia participation in GVC, Syafrian (2019) argues that Indonesia has four challenges in value upgrading; namely limited value capture, inefficiency, neoliberal regime and bad policies and institutions. Taking case of an automotive assembler in Indonesia, the author indicates that the assembler captures a limited value added because GVC lead firm designates Indonesia as a base to perform only low value added tasks from forward linkage such as marketing and after-sales. The assembler has never given opportunity by the lead firm to involve in high value added activities such as R\&D from backward linkage.

Based on Indonesia's undesirable performance outcomes in GVC, the primary objective of this paper is to understand the limitation of developing countries in taking part in GVC and upgrading along the value chain by taking Indonesia as an example. The paper focuses on exploring the process of value creation and value capturing of Indonesian suppliers within GVC governance. The paper is organized as follow: the next section discusses concepts used for analysis. It explores the concept of value creation, value capture, value chain, and governance in a business context. It follows by exploring governance in the context of globalization of value chain. It also discusses how data and information is gathered and analyzed. The following section discusses findings of this research. 
The last section concludes.

\section{Literature Review}

\subsection{Value Creation and Internationalization of Business}

Firms aim to obtain economic profit and this can be reached out not only by creating value but also creating higher value than competitors in the market. Value creation will be shared between consumers (surplus) and producer firms (profit). Product provides positive consumer surplus when the value of product is higher than the actual price of product paid by consumers (indicated by V-P in Figure 1). Meanwhile product provides positive profit for firms when the actual price of product received by firms is higher than cost of production per unit (C). Thus V-P and P-C represent the extent of value creation captured by consumers and producer respectively.

Value creation is dependent on the value of product and cost of production (VC). No product can be economically justifiable without a positive value creation $(\mathrm{V}>\mathrm{C})$. This implies that value enhancement or upgrading also depends on changes in both the value of product $(\Delta V)$ and the cost of production $(\Delta C)$. Consequently, firms scrutinize whether the (increase in) cost of production is comparable to the (increase in) value of product in deciding upgrading.

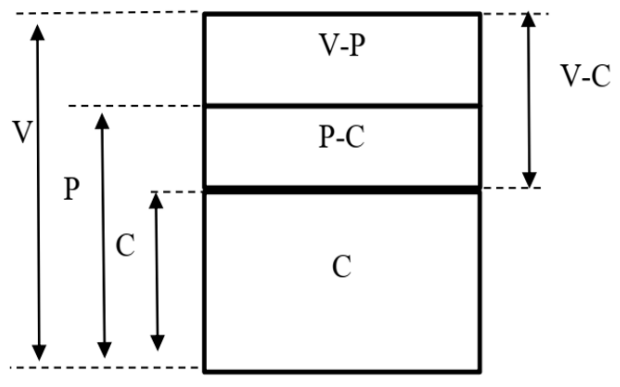

V: Value of product

P: Price per unit

C: Cost of production per unit

V-P: Consumer surplus per unit

P-C: Profit per unit

V-C: Value created per unit

Figure 2: Intra-firm Value Creation and Value Capturing

Value is also created across nation borders to foreign market that refers to internationalization of business. Theoretical framework of international business has been developed and significant models describe internationalization as a process of gradual development taking place in distinct stages over long period of time. The most popular 'stage' models of internationalization of business includes the Product Cycle (Vernon, 1966) and the Uppsala Internationalization Process model (Johanson \& Vahlne, 1977,2009). In general, the 'stage' models suggest internationalization follows a conventional route from arm's length market (exports-imports) toward vertical integration (foreign direct investment/FDI) thus value creation takes place within intra-firm business activities of a single 
producer firm. For instance, in the Product Cycle; value-created activities in the introduction stage is in home market. Exports support firm strategy to achieve economies of scale in lowering cost of production. In the growth stage, exports to foreign market increase and FDI becomes more favorable for firms to create higher profit in the foreign market. In the maturity stage indicated by saturation of the value of product perceived by consumers at home and foreign market, production facilities are relocated countries with low-cost countries (e.g. lower wage rate). Both home and foreign markets are supplied by imports. Finally, in the decline stage, the value of product is down, while the cost of production cannot be lower further thus firm may change their business.

\subsection{Value Chain and Inter-firm Relationship Value Creation}

Within a single firm, value is created through intra-firm relationship of business activities such as R\&D, product development, production, logistics, marketing and after sales. A value chain refers to a sequence of value-created activities of firm to bring goods and services from conception to final consumption (Kaplinsky, 2005). Porter (1985) classifies the value-created activities of firm into primary activities and support activities in which the classification enables firm to determine which activities can create higher value of product $(\mathrm{V})$ or lower costs (C). In doing so, firm can configure their value chain to generate higher value creation than competitors. Meanwhile, the concept of core competence in business strategy (Prahalad \& Hamel, 1990) makes it possible for firm to keep merely high value-created activities in-house in which firm has core competence, while outsource low value-created activities to other firms. This implies that value chain is sliced up (Timmer et al., 2014) and value is created within the inter-firm relationships rather than intra-firm relationships of a single firm.

The fragmentation of value chain results in a concept of governance, and scholars have provided explanations (See for example Coase, 1937; Williamson, 1979; Barzel, 2003). The inter-firm relationship value creation can take not only within arm's-length market but also in term of long term contracts, strategic alliances, joint ventures or parent-subsidiary relationships. The governance structure is dependent upon transaction costs incurred in making an exchange not only final goods but also intermediate goods, services or information. Transaction costs add up the cost of production in creating value thus firms are looking for additional revenue in order to offset the additional costs. Williamson (1979) argues that the transaction costs emerge when the inter-firm relationships value creation requires specific assets. In order to attract producer firms to invest in those specific assets, buyer are most likely to offer higher price (indicated by $\mathrm{P}^{*}$ in Figure 2) in order to generate quasi-rent that is extra profit captured by producers $\left(\mathrm{P}^{*} \mathrm{C}\right)$ in a fulfillment of the specific requirements of buyers. If the extra profit is large, producers will lose a lot if they do not take the offer. Nevertheless, the existence of the extra profit may lead to a condition of holdup in which ex post bargaining power deviate from ex ante bargaining power thus power relations 
between buyers and producers become asymmetry (Goldberg, 1976; Hart, 2009). Powerful firms could exploit this extra profit $\left(\mathrm{P}^{*} \mathrm{C}\right)$ over powerless firms through cost-price renegotiation. In most cases buyers gain relatively high ex post bargaining power thus they are able to capture higher profit $\left(\mathrm{P}-\mathrm{P}^{*}\right)$ than producers by incurring greater selling price $(\mathrm{P})$ and lower cost price $\left(\mathrm{P}^{*}\right)$. Value capture should make the benefits received by each parties to offset the costs incurred result in equitable distribution of value creation.

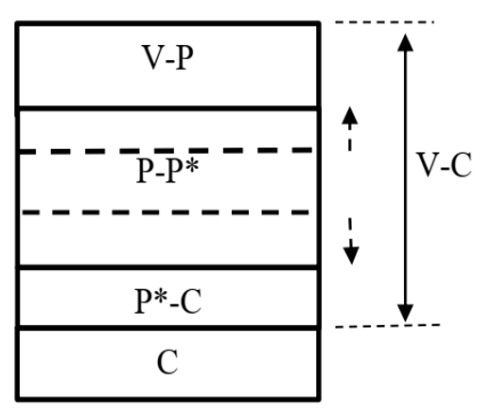

$\mathrm{V}$ : Value of product

P: Selling price per unit

$\mathrm{P}^{*}$ : Cost price per unit

C: Cost of production per unit

V-P: Consumer surplus per unit

P-P*: Profit per unit of buyers

P*-C: Profit per unit of producers

V-C: Value created per unit

Figure 3: Inter-firm Relationship Value Creation and Value Capturing

\subsection{Global Governance and Power Relations}

The inter-firm relationship value creation takes place not only within national boundaries by involving domestic lead firm and suppliers, but also across borders. This implies that the low value-created activities are not only outsourced but also offshored at the same time. Distinct value-created activities are performed by different firms and in dispersed site location around the world.

The fragmentation of value chains around the globe or globalization differs from the internationalization of business. Globalization involves not only the extension of value creation within the intra-firm relationships across the national boundary through exports and imports, but also the organization and coordination of value chain to create value within the inter-firm relationships (Dicken, 1998). Among others, the global value chains (GVC) (see Gereffi \& Korzeniewicz, 1994; Gereffi \& Memedovic, 2003; Gereffi et al., 2005) and the global production network (GPN) (see Henderson et al., 2002; Coe et al., 2004,2008; Coe \& Yeung, 2015) has acknowledged the globalization of value chains. The GVC highlights global governance system comprising of structure (i.e. network relationships in addition to arm's length market and vertical integration) and control and authority among participating firms in setting, executing and monitoring rules of the games. Thus transaction costs and power relations between firms are the underlying concepts for the development of analytical framework of the GVC. Power can make a single firm or some firms and institutions to influence behavior of others 
to have a conduct according to a set of rules; even in a manner contradicts to the others' interests (Coe \& Yeung, 2015). The governance structure and the power relations between firms within GVC is determined by a combination of three factors that are; (1) the complexity of information and knowledge required to create and enhance value, (2) the extent to which this information and knowledge can be codified, and therefore transmitted efficiently between participating firms (i.e. it may result in transaction costs) and (3) the firms' capability to complement each other to create value and to accomplish the whole value chain.

The distinct governance structure (i.e. market, modular, relational, captive and hierarchy) will determine the inter-firm relationship value creation and value upgrading (Gereffi et al., 2005). Value upgrading can be distinguished into process, product, functional and inter-sectoral or chain upgrading. Process upgrading involves activities to increase output or to reduce costs per unit output to increase value through productivity and efficiency. Product upgrading refers to activities to improve quality of product and to meet standards (e.g. technical, environment, labor). Functional upgrading refers to the extent of business functions performed by firms through increasing (upgrading) or reducing (downgrading) the number of tasks.

Finally, inter-sectoral or chain upgrading refers to the use of resources, capabilities and experience firms that are developed in one value chain to engage in others (Humphrey \& Schmitz, 2002; Kaplinsky, 2005). Value chain upgrading is not static buy dynamic subject to change over time. Value chain upgrading dynamics typically is moving from process upgrading to product upgrading and ultimately toward functional upgrading. The value chain upgrading within GVC highly depends on power relations between lead firm and suppliers. Although participating firms within GVC depend on each other and work together to generate value creation and to accomplish the whole value chain, power relations are rarely symmetrical. It is expected that problem of power asymmetry between firms within GVC is more significant than in domestic governance because the former involves greatly different level of firms' resources and capabilities.

Consequently, the high capable and resourceful global firms (mostly from developed countries) take a lead to drive the governance. They play their power to set and change rules of the game in order to include and exclude suppliers (mostly from developing countries), and to conditioning the behavior of them. Power relations and control certainly can drive upgrading dynamics of participating firms within GVC, but this will also result in asymmetric bargaining power between lead firms and suppliers. Powerful lead firms may incur fewer cost and receive greater price than suppliers. This implies that value creation captured by lead firms may be greater than suppliers. The important role of power relations in value creation and value upgrading is acknowledged by Coe and Yeung $(2015,2019)$. They capture three different typology of power, namely corporate, institutional (i.e. state) and collective (non-firm and non-state) power. The involvement of non-firm actors in the context of GVC governance makes power relations more asymmetric and it will affect the distribution of cost and 
price between suppliers and lead firms.

\section{Methodology}

The framework of value chain governance and inter-firm relationship value creation provides the basis for the empirical ground toward which this study is addressed. To obtain the empirical basis for the analysis, this study collects primary qualitative data through interviews with top executives of Indonesian firms across palm oil, garment and electronics industries supplying for lead firms to discover insights into their decision making to engage in GVC and to upgrade along GVC. Those industries are selected due to their significant contribution to domestic production and exports of Indonesia. Nevertheless, the upgrading of those industries in global market is still limited reflected by a stagnant unit value of the exports over time. This study emphasizes on assessing what are the explanations associated with the limited value upgrading within GVC from the perspective of electronics, garment and palm oil suppliers in Indonesia. Thus this study covers only the one side of inter-firm relationships. The author is aware of this limitation of the study that should collect the views of the both sides. Nevertheless, this does not impair the understanding of value creation and value capture within GVC from the perspective of Indonesia suppliers in order to apply, test and improve concept and theory.

The study relies on in depth interview as instrument to collect information from purposively selected participants across industries. Each interview is carried out face to face for a session of 1.5 to 2 hours between 2008 and 2016 involving 4 (four) palm oil producers, 7 (five) garment producers and 4 (four) consumer electronics producers (Appendix 1). The interviews are unstructured and are carried out in Bahasa, the official language of Indonesia, and are recorded and transcribed into texts in order to apply the narrative analysis (Bryman, 2012). The participants are in general requested to share their experiences in supplying products for global lead firms mostly from EU and US.

The accounts shared by the participants are coded beginning with open coding to generate concepts of value upgrading and its dynamics in the context of participants. Then they are proceeded with axial coding to relate and compare the concepts to generate categories. At the final stage, selective coding generates the core category to form the narrative analysis that describes the process and the context of value upgrading within industries (Bryman, 2012). The coding process is conducted in the original language of Bahasa in order to avoid lost in meaning due to translation. The author translates with great accuracy only those excerpts of interview to use it as quotes.

The accounts of value creation and value capturing are ultimately analyzed to obtain perspectives on value creation and value capturing within GVC. Because the analysis and concluding remark of this paper relies on the interpretation of the perspective shared by the top executives of few producers, thus the likeliest possible explanation for the core concepts is based on abductive reasoning (Bryman, 
2012). The author is also aware of the limitations of this cross cases analysis that is the empirical findings cannot be used to generalize to the industry-level of palm oil, garment and electronics in Indonesia. Nevertheless, the analysis can provide detailed accounts and in-depth insights into the inter-firm relationship value creation and value capturing within GVC governance (Yin, 2003; Bryman, 2012).

\section{Results and Discussions}

\subsection{Product Upgrading in Global Palm Oil Value Chain}

Within GVC governance, standardization plays a vital role to include firms to participate and to ease inter-firms relationship value creation. Standards are mostly set, monitored and executed within multi-stakeholder initiatives (MSI) comprises consumers, buyers, producers and other institutions. Thus the MSI-driven standards are usually voluntary basis in which they apply only for producerbuyer firms and other institutions that are participating member of the MSI. In many agricultural commodities, including palm oil, sustainability has become the standard widely adopted within GVC governance. Thus MSI-driven sustainability standards in the agricultural commodities play important role in shaping the mechanism of GVC governance (Cashore, 2002; Bernstein \& Cashore, 2007; Eberlein et al., 2014; Ponte \& Cheyns, 2013). Within global palm oil value chain, various MSI administer sustainability standards and certification mechanisms including the Roundtable on Sustainability Palm Oil (www.rspo.org) and International Sustainability \& Carbon Certification (www.iscc-system.org). The RSPO is still the most influental organization that governs global sustainability standards in palm oil commodity. The RSPO sets sustainable palm oil standards by taking into account the three pillars of environmental conservation, economic profit and social welfare. The standards mainly aim to minimize the negative impact of palm oil burgeoning business on environmental and social degradation. Certification and labeling (Certified Sustainable Palm Oil-CSPO) mechanisms are used by the RSPO to inform consumers, market and society that palm oil producers have complied with the sustainability standards.

Nevertheless, the sustainability outcomes, particularly environmental conservation within the RSPO-driven palm oil GVC is still limited. Some scholars argue that this limitation is because the RSPO takes into account the principle that environmental, social and economic pillars of sustainability can be reconciled rather than conflicting to each other (see for instance Schouten et al., 2012; Brandi, 2017). In fact, making decisions to comply with the RSPO's sustainable palm oil standards (i.e. product upgrading) requires trading off environmental conservation against economic gains. Consequently, palm oil suppliers have to consider the compliance costs of CSPO; whether it is economically justifiable or not. If these increase costs of production $(\mathrm{C})$ are not compensated by the increase price $\left(\mathrm{P}^{*}\right)$, this results a lower profit or values captured by the palm oil suppliers. 
In this case, the RSPO's sustainable palm oil standards are not economically justifiable. For this reason, some Indonesian palm oil suppliers decide not to perform product upgrading to meet the RSPO's sustainability standard, instead they decouple from the RSPO-driven GVC and recouple in global market not driven by the RSPO's sustainability standard including India and China. Palm oil suppliers perceives by decoupling from GVC leads to positive impact on the development of palm oil industry in Indonesia. This is highlighted by a statement of participant:

"Business deal is taking place between producers and buyers in which they will look at whether the deals are realistic, viable, can be executed or not. When we deal with particular buyers asking for specific requirements thus as long as the requirements are economically reasonable and viable we will take the deal. .... This is a matter of choice for us to select the types of buyers (top executive of palm oil producer 3 , personal communication, June 23, 2016).

Furthermore, value created due to product upgrading of Indonesian palm oil supplier (i.e. producing the CSPO product) may not be equitable captured. In fact the costs burden of the CSPO certification processes are fully born by palm oil suppliers, while there is no price premium paid by lead firm to compensate the costs differential. In addition, the sustainability standard changed more frequently by the RSPO in which it becomes more and more difficult to meet by palm oil suppliers (e.g. the RSPO Next ${ }^{2}$ ). The supplier perceives the inequitable distribution of value capture with global lead firm within the RSPO-driven palm oil GVC is influenced by power asymmetry among involved parties. Global lead firms tend to be more demanding due to the pressures of other parties (i.e. global environmental NGOs) and the product upgrading is now beyond the governance between suppliers and global firms (i.e. corporate power). This make power relations between suppliers and global lead firms more asymmetric leads to a more inequitable distribution of product upgrading. This is indicated by a statement of other participant.

The raising standards have deviated from the original idea of the RSPO's establishment to ensure a continuous market supply of palm oil. The adoption of the rising standards is particularly due to pressure from international environmental NGOs. The RSPO-driven palm oil GVC is not driven by market within the relationships between

\footnotetext{
${ }^{2}$ the RSPO Next includes: (1) banning planting palm oil on peatlands and other carbon-rich soils (pre-existing standards only banning the cutting of primary forests or those considered to be of high conservation value), (2) requiring plantations to implement fire prevention policies (versus no requirement of plantations to have procedures in place to prevent fire on land they manage), (3) reducing greenhouse gas emissions (versus a less comprehensive reduction requirements), (4) paying employees a living wage and commit to zero deforestation (versus only extensive planting on peatland) (Guardian, 2016).
} 
suppliers and buyers, but third parties. The third parties provide asymmetric information on sustainability practices in palm oil producing countries such as Indonesia and they influence the public debate and public policy in the buying countries (top executive of palm oil producer 4, personal communication, May 24, 2018).

\subsection{Process and Functional Upgrading in Global Garment Value Chain}

Process upgrading and functional upgrading is the most likely to be gained by suppliers from developing countries participating in GVC (Humphrey \& Schmitz, 2002). In garment industry many scholars (see for instance Bair \& Gereffi, 2003; Nadvi et al., 2004; Kenta, 2007; Tokatli, 2007) have identified how garment suppliers are able to increase their business functions from the cut-maketrim (CMT) arrangement toward the develop-purchase (or the FOB arrangement) including tasks in making pattern and sample, and purchasing materials (e.g. fabrics, thread, buttons). While the functional upgrading by taking additional production activities can provide higher price received by garment suppliers, nevertheless the additional functions also incur higher costs of production and higher risks as well. In some cases, the additional cost due to the functional upgrading is lower than the risks; thus garment suppliers may discourage to promote from the CMT to the FOB by increasing tasks performed.

The (CMT) price of garment for export is higher than for domestic market, but international buyers require more stringent specifications. Comparing with the CMT, the FOB price may give the producer additional profit margin coming from fabrics, accessories, thread and so on due to those inputs are sourced by the producer. Nevertheless, the additional (profit) margin can be only captured if there is no problem during the production processes. The price received by suppliers may be higher in the FOB arrangement, but the costs (and risks) of production are also higher (top executive of the garment producer 1 , personal communication, March 15, 2008 and October 24, 2014).

Similar story applies to the product upgrading when garment suppliers move from producing low quality basic garment (e.g. uniforms, t-shirt) to high quality and more complicated fashion garment. The product upgrading provides higher value creation but it does not necessarily generate higher value capture for garment suppliers. Instead, global lead firms are likely to capture more on value creation.

Comparing to the uniforms, the fashion garment is more difficult and it is not necessarily providing higher profit. The (cost) price of the fashion garment is higher (than the uniforms) but it requires more workloads. We have evaluated (the value capture between the uniforms and the fashion garment) and decided that the fashion 
garment is not (economically) viable for us. We prefer making the uniforms with price lower than fashion garment because the making of the fashion garment will expose us with higher risks. Consequently, at the end we may not capture higher value but only more workloads (top executive of the garment producer 1, personal communication, March 15, 2008 and October 24, 2014).

Higher value may be captured by suppliers through lowering the cost of production per unit $(C)$ rather than increasing the price per unit $\left(\mathrm{P}^{*}\right)$ paid by global lead firms despite their requirement of specific assets.

Costing activity is the most important factor to compete, because global lead firms are squeezing the price. In addition, global lead firms are not asking only for high garment quality and competitive cost , but also social compliance. The experience of us indicates that for the beginning, taking order from global lead firms was not profitable, because we had to invest to meet global lead firms' requirements such as special warehouse, facilities for employees and so on. Over time we learns a good manufacturing system from global lead firms including cost of production savings to generate profit (top executive of garment producer 4, personal communication, May 30, 2008).

\subsection{Functional Downgrading in Global Consumer Electronics Value Chain}

Value chain upgrading is not a typical consequentiality within GVC. Empirical evidence also demonstrates the cases of global value chain downgrading in which firms and industry have reduced business functions from activities in design, $\mathrm{R} \& \mathrm{D}$, branding, sales/after sale services to only manufacturing tasks when they are recoupling in GVC (see for instance Rabellotti, 2004; Bair \& Peters, 2006). In the electronics industry, evidence shows that suppliers are engaging in a number of governance at the same time by separating their businesses as manufacturer brands from contract manufacturer or the ODM spin-offs (Sturgeon \& Kawakami, 2011).

The long historical story of an electronics supplier in Indonesia indicates the nature of the ODM spin-offs in which the supplier is separating its manufacturer brands of consumer electronics (e.g. television, audio, audio multimedia and home appliances) from contract manufacturer of wireless telecommunication devices (e.g. 4G LTE). This business development of the supplier is made mostly based on the value capture rather than value creation. When the value of its ownbrand electronics cannot be enhanced further (i.e. through product innovation) thus the supplier downsizes the consumer electronics business, while shifting to the wireless telecommunication devices despite the changing role of supplier by acting as the contract manufacturer. It suggests that functional downgrading rather than upgrading is sometimes a path to capture higher value and profit 
(suggested also by Amighini \& Rabelloti, 2006). Consequently suppliers may perform strategic decoupling and recoupling to ensure a higher value capture (Horner, 2014).

In the past, we developed many innovative products to meet consumers' needs, nevertheless at the end we realised that the innovative products did not always attract consumers to buy the products, in particular when consumers did not appreciate the innovatiness too much. Consumers were willing to buy the innovative products, but they were willing to pay additional price (for the innovativeness) lower than the additional costs of production incurred in the innovativeness. Moreover we now see a greater business opportunity in telecommunication devices. Thus we have diversified capabilities to include ICT product manufacturing to keep up with rising opportunity. We create partnerships (as contract manufacturer) with Huawei to manufacturing the $4 \mathrm{G}$ devices to be installed in its smartphones. The partnerships also aim to comply with the 30 percent local content requirement in electronic products enacted by the Government of Indonesia (top executive of electronics producer 2, personal communication, March 252008 and May 12, 2016).

Through the analysis of interview transcripts from key informants across different industries in Indonesia, it indicates that a decision to participate or not (coupling and decoupling) and upgrade or downgrade (i.e. process, product and functional) in the context of GVC is also made by suppliers in addition to lead firms. Indonesian palm oil, garment and electronics suppliers take costs/risks incurred and benefits received into a consideration when decide to participate and to upgrade within GVC. Suppliers perceive that participating in GVC and performing process, product and functional upgrading will not automatically provide higher value added (i.e. benefit-cost disparity) for them. Value capture plays more important role than value creation in encouraging the suppliers to participate and to upgrade within GVC governance. The evidence also indicates that the distribution of costs/risks incurred and price received between suppliers and global lead firms are not equitable. This is because of power asymmetry between suppliers and GVC lead firms empowered by non-firm institutions (e.g. state and NGOs).

\section{Concluding Remarks}

The emergence of the GVC is a reflection of changes in business governance within the globalization context. Value is created within the inter-firm relationships comprised firms and institutions come from around the globe. The governance structure to create value is not limited merely on the arm's length market and the vertical integration. This globalization of value chain has promoted opportunities particularly for suppliers from developing countries to participate in 
value creation and upgrading within the relationships with global lead firms from developed countries as argued by many scholars. Nevertheless, the participation of developing countries in GVC is relatively low and the upgrading outcomes resulted in the GVC are still limited.

Empirical evidence at the firm-level across palm oil, garment and electronics industry in Indonesia sheds light on their impediment to participate in GVC and to upgrade along the value chain. The narratives of participants demonstrate that product upgrading in term of compliance with standards (i.e. sustainability and labor standards) and functional upgrading (i.e. increasing tasks performed by suppliers) driven by GVC lead firms make the costs of production up. Upgrading within GVC will be economically justifiable if the price received by suppliers is also up. Similar argument also applies for the functional downgrading in which the reduction of business activities will be economically viable when the action can capture more value added and profit.

The GVC has highlighted the concept of the governance in value creation including the forms of inter-firm relationships, nevertheless the GVC pays little attention to the distribution of value creation (i.e. value capture) between parties. This paper suggests that the value creation and value capture should be separated in analysis of GVC governance. Suppliers may capture less value while creating more value than global lead firms. Suppliers will be more interested in creating and upgrading value if they do not receive less of the value they create. This implies that the GVC framework should also provide accurate presentation of the value capture by measuring the value added received by the global buyers (i.e. $\mathrm{P}_{-} \mathrm{P}^{*}$ disparity) and the value added received by suppliers (i.e. $\mathrm{P}^{*}-\mathrm{C}$ disparity).

This paper also suggests that in the condition of the different level of resources, capabilities and experiences between suppliers from developing countries and global lead firms from developed countries, it is expected that the power relations are asymmetry. Furthermore, the GVC governance is now beyond inter-firm relationships because the involvement of non-firm institutions in the governance. Global lead firms empowered by non-firm institutions are most likely to be more powerful than suppliers, thus they take control in the relationship. Consequently, global lead firms can capture more value than suppliers by incurring fewer price (i.e. $P^{*}$ ).

Understanding that the inequitable distribution of cost and benefit in value capture impedes Indonesian suppliers to participate and to upgrade within GVC governance, policy should be established to make suppliers capture more equitable value created in a relationship with global lead firms. The policy should be emphasized to strengthen distinctive resources and capabilities of suppliers in order to increase bargaining power in dealing with global lead firms.

Although these important contributions, some limitations should be recognized to provide a balanced discussion of the findings. First, the findings are based on the perception from the side of suppliers without insights from the side of global lead firms. Future researches should examine the insights of global firms and non-firms because GVC governance involves two or more parties. Second, 
the findings rely on qualitative research of cross cases that cannot be generalized into population of palm oil, garment and electronics industry in Indonesia. Future researches should be conducted quantitatively to generate outcomes that can be generalized.

\section{References}

[1] Amighini, A., \& Rabellotti, R. (2006). How do Italian footwear industrial districts face globalization?. European Planning Studies, 14(4), 485-502. doi:10.1080/09654310500421105.

[2] Bair, J. \& Gereffi, G. (2003). Upgrading, uneven development and jobs in the North American apparel industry. Global Networks, 3(2), 143-169. doi:10.1111/14710374.00054.

[3] Bair, J., \& Peters, E. D. (2006). Global commodity chains and endogenous growth: export dynamism and development in Mexico and Honduras. World Development, 34(2), 203-221. doi:10.1016/j.worlddev.2005.09.004.

[4] Barzel, Y. (2005). Organizational forms and measurement costs. Journal of Institutional and Theoretical Economics (JITE)/Zeitschrift für die gesamte Staatswissenschaft, 161(3), 357-373. doi: 10.1628/093245605774259291.

[5] Bernstein, S., \& Cashore, B. (2007). Can non-state global governance be legitimate? An analytical framework. Regulation \& Governance, 1(4), 347-371. doi: 10.1111/j.17485991.2007.00021.x.

[6] Brandi, C. A. (2017). Sustainability standards and sustainable development-synergies and trade-offs of transnational governance. Sustainable Development, 25(1), 25-34. doi: $10.1002 /$ sd.1639.

[7] Bryman, A. (2012). Social research method (4th edition). Oxford: Oxford University Press.

[8] Cashore, B. (2002). Legitimacy and the privatization of environmental governance: How non-state market-driven (NSMD) governance systems gain rule-making authority. Governance, 15(4), 503-529. doi: 10.1111/1468-0491.00199.

[9] Coase, R. H. (1937). The nature of the firm. Economica, 4(16), 386-405. doi: 10.1111/j.1468-0335.1937.tb00002.x.

[10] Coe, N. M., \& Yeung, H. W. C. (2015). Global production networks: Theorizing economic development in an interconnected world. Oxford University Press.

[11] Coe, N. M., \& Yeung, H. W. C. (2019). Global production networks: Mapping recent conceptual developments. Journal of Economic Geography, 19(4), 775-801. doi: $10.1093 / \mathrm{jeg} / \mathrm{lbz} 018$.

[12] Coe, N. M., Dicken, P., \& Hess, M. (2008). Global production networks: realizing the potential. Journal of Economic Geography, 8(3), 271-295. doi: 10.1093/jeg/lbn002.

[13] Coe, N. M., Hess, M., Yeung, H. W. C., Dicken, P., \& Henderson, J. (2004). 'Globalizing' regional development: a global production networks perspective. Transactions of the Institute of British Geographers, 29(4), 468-484. doi: 10.1111/j.0020-2754.2004.00142.x.

[14] Dicken, P. (1998). Global shift: Transforming the world economy (3rd edition). London: Paul Chapman Publishing.

[15] Eberlein, B., Abbott, K. W., Black, J., Meidinger, E., \& Wood, S. (2014). Transnational business governance interactions: Conceptualization and framework for analysis. Regulation \& Governance, 8(1), 1-21. doi: 10.1111/rego.1203. 
[16] Gereffi, G., \& Korzeniwicz, R. (Eds.) (1994). Commodity chains and global capitalism. London: Greenwood Press.

[17] Gereffi, G. \& Memedovic, O. (2003). The global apparel value chain: What prospects for upgrading by developing countries. United Nations Industrial Development Organization. Retrieved from https://www.unido.org/sites/default/files/2009-12/ Global_apparel_value_chain_0.pdf.

[18] Gereffi, G., Humphrey, J., \& Sturgeon, T. (2005). The governance of global value chains. Review of International Political Economy, 12(1), 78-104. doi: 10.1080/09692290500049805.

[19] Goldberg, V. P. (1976). Regulation and administered contracts. The Bell Journal of Economics, 7(2), 426-448. doi: 10.2307/3003265.

[20] Guardian. (2016, February 9). Critics fear RSPO's stricter palm oil standards will create two-tier system. Retrieved from https: //www.theguardian.com/sustainable-business/2016/feb/09/ palm-oil-stricter-standards-rspo-next-deforestation-human-rights-boots-ferrerodanone.

[21] Hart, O. (2009). Hold-up, asset ownership, and reference points. The Quarterly Journal of Economics, 124(1), 267-300. doi: 10.1162/qjec.2009.124.1.267.

[22] Henderson, J., Dicken, P., Hess, M., Coe, N., \& Yeung, H. W. C. (2002). Global production networks and the analysis of economic development. Review of International Political Economy, 9(3), 436-464. doi: 10.1080/09692290210150842.

[23] Horner, R. (2014). Strategic decoupling, recoupling and global production networks: India's pharmaceutical industry. Journal of Economic Geography, 14(6), 1117-1140. doi: https://doi.org/10.1093/jeg/lbt022.

[24] Humphrey, J., \& Schmitz, H. (2002). How does insertion in global value chains affect upgrading in industrial clusters?. Regional Studies, 36(9), 1017-1027. doi: $10.1080 / 0034340022000022198$.

[25] Johanson, J., \& Vahlne, J. E. (1977). The internationalization process of the firm-a model of knowledge development and increasing foreign market commitments. Journal of International Business Studies, 8(1), 23-32. doi: 10.1057/palgrave.jibs.8490676.

[26] Johanson, J., \& Vahlne, J. E. (2009). The Uppsala internationalization process model revisited: From liability of foreignness to liability of outsidership. Journal of International Business Studies, 40(9), 1411-1431. doi: 10.1057/jibs.2009.24.

[27] Kaplinsky, R. (2005). Globalisation, poverty and inequality: Between a rock and a hard place.. Cambridge: Polity Press.

[28] Kenta, G. (2007). Industrial upgrading of the Vietnamese garment industry: An analysis from the global value chains perspective. RCAPS Working Paper No.07-1. Ritsumeikan Center for Asia Pacific Studies (RCAPS), Ritsumeikan Asia Pacific University. Retrieved from http://www.apu.ac.jp/rcaps/uploads/fckeditor/publications/ workingPapers/RCAPS_WP07-1.pdf.

[29] Mudambi, R. (2008). Location, control and innovation in knowledge-intensive industries. Journal of Economic Geography, 8(5), 699-725. doi: 10.1093/jeg/lbn024.

[30] Nadvi, K., Thoburn, J. T., Thang, B. T., Ha, N. T. T., Hoa, N. T., Le, D. H., \& Armas, E. B. D. (2004). Vietnam in the global garment and textile value chain: impacts on firms and workers. Journal of International Development, 16(1), 111-123. doi: 10.1002/jid.1066.

[31] OECD. (2017). TiVA 2016 Indicators - Definitions. Organisation for Economic Cooperation and Development. Retrieved from http://www.oecd.org/sti/ind/tiva/ TIVA_2016_Definitions.pdf. 
[32] Ponte, S., \& Cheyns, E. (2013). Voluntary standards, expert knowledge and the governance of sustainability networks. Global Networks, 13(4), 459-477. doi: 10.1111/glob.12011.

[33] Porter, M. (1985). The competitive advantage: Creating and sustaining superior performance. New York: Free Press.

[34] Prahalad, C. K., \& Hamel, G. (1990). The core competence of the corporation. Harvard Business Review, 68(3), 79-91.

[35] Rabellotti, R. (2004). How globalisation affects Italian industrial districts: the case of Brenta. In H. Schmitz (Ed.), Local enterprises in the global economy: Issues of governance and upgrading (pp. 140-173), Edward Edgar.

[36] Schouten, G., Leroy, P., \& Glasbergen, P. (2012). On the deliberative capacity of private multi-stakeholder governance: the roundtables on responsible soy and sustainable palm oil. Ecological Economics, 83, 42-50. doi: 10.1016/j.ecolecon.2012.08.007.

[37] Syafrian, D. (2019). Upgrading Challenges in Global Value Chains. Proceedings of the International Conference on Trade 2019 (ICOT 2019), Advances in Economics, Business and Management Research, volume 98 (pp. 168-172). Atlantis Press. doi: https://dx.doi.org/10.2991/icot-19.2019.36.

[38] Sturgeon, T. J., \& Kawakami, M. (2011). Global value chains in the electronics industry: characteristics, crisis, and upgrading opportunities for firms from developing countries. International Journal of Technological Learning, Innovation and Development, 4(1-3), 120-147. doi: 10.1504/IJTLID.2011.041902.

[39] Timmer, M. P., Erumban, A. A., Los, B., Stehrer, R., \& De Vries, G. J. (2014). Slicing up global value chains. Journal of Economic Perspectives, 28(2), 99-118. doi: 10.1257/jep.28.2.99.

[40] Tokatli, N. (2007). Asymmetrical power relations and upgrading among suppliers of global clothing brands: Hugo Boss in Turkey. Journal of Economic Geography, 7(1), 67-92. doi: $10.1093 / \mathrm{jeg} / \mathrm{lbl} 017$.

[41] Vernon, R. (1966). International investment and international trade in the product cycle. The Quarterly Journal of Economics, 80(2), 190-207. doi: 10.2307/1880689.

[42] Williamson, O. E. (1979). Transaction-cost economics: the governance of contractual relations. The Journal of Law and Economics, 22(2), 233-261. 10.1086/466942.

[43] WTO. (2017). Trade in value-added and global value chains: statistical profiles. World Trade Organization. Retrieved from https://www.wto.org/english/res_e/statis_e/ miwi_e/countryprofiles_e.htm.

[44] Yin, R. (2003). Case study research: Design and methods (3rd edition). California: Sage Publications. 


\section{Appendix}

Table A1: List of Interviews

\begin{tabular}{clll}
\hline No & Participant(s) - anonymity & Location & Date \\
\hline 1 & Palm oil producer to executive 3 & Jakarta & 07-Mar-14 \\
2 & Palm oil producer top executive 2 & Jakarta & 23-Aug-14 \\
3 & Palm oil producer top executive 3 & Jakarta & 23-Jun-16 \\
4 & Palm oil producer top executive 4 & Jakarta & 24-May-18 \\
5 & Garment producer top executive 1 & Jakarta & 15 March 2008 \& 24 October 2014 \\
6 & Garment producer top executive 2 & Jakarta & 15-May-08 \\
7 & Garment producer top executive 3 & Jakarta & 13-Jun-08 \\
8 & Garment producer top executive 4 & Semarang & 30-May-08 \\
9 & Garment producer top executive 5 & Bandung & 02-Jun-08 \\
10 & Garment producer top executive 6 & Jakarta & 12-Jun-08 \\
11 & Garment producer top executive 7 & Bandung & 08-Jul-08 \\
12 & Electronics producer top executive 1 & Jakarta & 07-May-08 \\
13 & Electronics producer top executive 2 & Surabaya \& Jakarta & 25 March 2008 \& 12 May 2016 \\
14 & Electronics producer top executive 3 & Jakarta & 21-May-08 \\
15 & Electronics producer top executive 4 & Jakarta & 06-Jun-08 \\
\hline
\end{tabular}

